\title{
NITROGENOUS COMPOUNDS, PHENOLIC COMPOUNDS AND MORPHOLOGICAL ASPECTS OF LEAVES: COMPARISON OF DECIDUOUS AND SEMIDECIDUOUS ARBOREAL LEGUMES
}

\author{
Ana Lúcia da Silva Limaㄹ Fábio Zanellaㅜ; Marlene Aparecida Schiavinato²; Claudia Regina \\ Baptista Haddad ${ }^{2 *}$ \\ ${ }^{1}$ ULBRA/CEULJI - Depto. de Biologia e Agronomia, C.P. 271 - 78961-970 - Ji- Paraná, RO - Brasil. \\ ${ }^{2}$ UNICAMP/IB - Depto. de Fisiologia Vegetal, C.P. 6109 - 13083-862 - Campinas, SP - Brasil. \\ *Corresponding author <chaddad@unicamp.br>
}

\begin{abstract}
In general, perennial species contain higher concentrations of certain secondary compounds, such as phenolics, lower levels of nitrogenous compounds, and greater specific leaf mass (SLM) than deciduous species. The aim of this study was to verify whether the comparative data reported in the literature regarding deciduous and evergreen species, also applies to four selected species of a semideciduous tropical forest (a remnant of the Atlantic Forest). The four species chosen for this study, each with apparently different leaf life spans, were two semideciduous (Hymenaea courbaril L. var. stilbocarpa (Hayne) Lee et Lang., and Lonchocarpus guilleminianus (Tul.) Malme, and two deciduous (Enterolobium contortisiliquum (Vell.) Morong., and Peltophorum dubium (Spreng.) Taub.). Plants were grown in a greenhouse in plastic pots containing soil taken from their natural habitat. Mature leaves were harvested for determination of the SLM and contents of phenolic compounds, tannins, nitrate, protein, free amino acids, chlorophyll, and nitrogen. Data registered are in agreement with those of the literature. Leaves with the longest life span had the highest content of phenolics and the lowest levels of tannins, nitrate, protein, amino acids, chlorophyll and nitrogen, as well as presenting the greatest SLM.
\end{abstract}

Key words: leaf life span, specific leaf mass, total nitrogen, tannins, Atlantic forest

\section{COMPOSTOS NITROGENADOS, FENÓLICOS E ASPECTO MORFOLÓGICO EM FOLHAS: COMPARAÇÃO ENTRE LEGUMINOSAS ARBÓREAS SEMIDECÍDUAS E DECÍDUAS}

\begin{abstract}
RESUMO: Em geral as espécies perenifólias possuem maior concentração de alguns compostos secundários, como por exemplo fenóis, menor concentração de compostos nitrogenados e maior massa foliar específica (MFE), quando comparadas a espécies decíduas. O objetivo deste trabalho foi verificar se as observações encontradas na literatura, comparando espécies perenifólias e decíduas aplicam-se também a quatro espécies de uma mata semidecídua, remanescente da Mata Atlântica. Das quatro espécies usadas neste estudo, que aparentemente apresentavam longevidades foliares diferentes, duas eram semidecíduas (Hymenaea courbaril L. var. stilbocarpa (Hayne) Lee et Lang. e Lonchocarpus guilleminianus (Tul.) Malme) e duas decíduas (Enterolobium contortisiliquum (Vell.) Morong. e Peltophorum dubium (Spreng.) Taub.). As plantas foram cultivadas em vasos plásticos, contendo solo da mata. O cultivo foi feito em casa de vegetação. Folhas maduras foram coletadas para análise de fenóis totais, taninos condensados, nitrato, proteínas totais, aminoácidos livres totais, clorofila total, nitrogênio total e MFE. Os resultados obtidos corroboram os da literatura, já que as espécies com folhas mais longevas apresentaram concentrações maiores de fenóis totais, menores de taninos condensados, nitrato, proteínas solúveis totais, aminoácidos livres totais, clorofilas totais, nitrogênio total e maior MFE.

Palavras-chave: longevidade foliar, massa foliar específica, nitrogênio total, taninos, floresta Atlântica
\end{abstract}

\section{INTRODUCTION}

Comparative studies of the nutrient content of leaves from perennial and deciduous species have revealed that the lowest levels occur in species which leaves have the longer life span (Wright \& Westoby,
2003). The longer life span of leaves of perennial species and their lower nitrogen content are important factors regarding the economy of this nutrient. Such plants benefit from leaves that function for a longer period using less nitrogen (Carrera et al., 2000; 2003). 
The perennials have a low photosynthetic rate due to their low levels of Rubisco and chlorophyll (Ingestad \& Lund, 1979). Such species invest more in secondary compounds and tissues for structural support (Chabot \& Hicks, 1982), which may explain the lower nitrogen content of their leaves. By contrast, species that have high photosynthetic rates invest more in organic compounds, especially nitrogenous (Field \& Mooney, 1986 in Cordell et al., 2001). One explanation for the fact that perennials have lower nitrogen content in their leaves is that such species have greater concentrations of phenolic compounds than do leaves with shorter life span (Coley et al., 1985), and the synthesis of these compounds competes with that of the nitrogenous compounds (Kouki \& Manetas, 2002).

One possible reason for a higher concentration of phenolic compounds in perennial leaves could be the greater need for a defense mechanism against herbivorous predators due to their longer life span (Aerts, 1990). Phenolic compounds are known to participate in the defense against herbivores (Hudgins et al., 2003) and pathogenic attack (Haukioja et al., 1985). On the other hand, tannins are often present in higher concentration in deciduous species (Aerts, 1995).

Species that have leaves with a longer life span generally have a lower specific leaf area (SLA) (Eamus \& Prichard, 1998), or higher specific leaf mass (SLM), due to the leaf blades and cuticles being thicker, as well as a larger lignified area (Read et al., 2000). This results in an increased mass to area ratio, which permits such leaves to resist adverse conditions for a longer time (Gates, 1914 in Chabot \& Hicks, 1982).

The Atlantic Forest has been reduced to only $7 \%$ of its original area (Araújo et al., 2004). However little is known of the relationship between leaf life span and conservation of nutrients for species of this ecosystem, even though such knowledge is important for the recovery of degraded areas with native species.

The aim of this study was comparing two semideciduous with two deciduous species, taken from a semideciduous forest (a remnant of the Atlantic Forest), regarding leaf longevity in relation to certain metabolic components (total nitrogen, nitrogenous and secondary compounds), and morphological characteristics (SLM) of mature leaves.

\section{MATERIAL AND METHODS}

\section{Species and habitat characterization}

Seeds of arboreal legume species were taken from a semideciduous tropical forest, a remnant of the
Atlantic Forest, denominated the Santa Genebra Municipal Reserve, region of Campinas, São Paulo State,

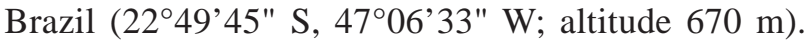
The Santa Genebra forest is classified as semideciduous because it has several arboreal species with seasonal lost of leaves, that occurs in the dry and cold period of the year (Morellato, 1995). The species used in this study were: Hymenaea courbaril L. var. stilbocarpa (Hayne) Lee et Lang., Lonchocarpus guilleminianus (Tul.) Malme, Enterolobium contortisiliquum (Vell.) Morong., and Peltophorum dubium (Spreng.) Taub., the first two classified as semideciduous and the last two as deciduous (Lorenzi, 1992). The semideciduous species lose their leaves to a greater extent during a period of the year but never remain totally without leaves. Deciduous species lose their leaves in a specific period of the year, when they remain totally, or almost totally, without leaves (Morellato et al., 1989).

\section{Seed germination}

Seeds of $H$. courbaril and E. contortisiliquum were scarified with concentrated sulphuric acid for 1 hour and those of $P$. dubium for 30 minutes, followed by thorough washing with water. Seeds from the four species were then left to germinate at $25^{\circ} \mathrm{C}, 12$ hours photoperiod.

\section{Growth conditions}

The experiments were carried out from January, 2001 to March, 2003. Plants were grown under natural light and temperature conditions in a greenhouse, in plastic pots (5 L capacity) containing soil taken from the Santa Genebra Reserve. Plastic saucers were used under the pots and irrigation carried out using a sprinkler system.

To ensure nodulation in species associated with rhizobia (L. guilleminianus and E. contortisiliquum), inoculation was carried out with slow growth rhizobia strains (2 mL per pot), previously isolated from root nodules (Vincent, 1970), from the same species grown in the Santa Genebra forest soil.

\section{Evaluation of leaf development and leaf character- ization}

Growth curves were constructed based on leaf rachis length in order to determine when leaf expansion was completed for harvest and analysis. The mean length of fully expanded leaves (mature-green) of each of the studied species was: $H$. courbaril $8.8 \pm 2.2 \mathrm{~cm}$; L. guilleminianus $17.8 \pm 3.5 \mathrm{~cm}$; P. dubium $6.7 \pm 0.4$ $\mathrm{cm}$; and E. contortisiliquum $13.9 \pm 2.9 \mathrm{~cm}$. For the determination of leaf longevity, the same leaves used for measurement were date-tagged with strips of plastic around the petioles. 


\section{Determination of SLM}

SLM was calculated using the formula: SLM

$=\mathrm{DM}_{\text {mature-green leaves }} / \mathrm{A}_{\text {mature-green leaves }}\left(\mathrm{g} \mathrm{cm}^{-2}\right)$, where $\mathrm{DM}$ $=$ dry mass, and $\mathrm{A}=$ leaf area. Dry mass was obtained after leaves were kept in oven at $60^{\circ} \mathrm{C}$ for 7 days. Leaf area was obtained using a LI-COR instrument, model LI-300.

Determination of total phenolics, condensed tannins, nitrate, soluble protein and free amino acids

Leaves (500 mg fresh mass) were macerated using liquid $\mathrm{N}_{2}$ and extracted with methanol, chloroform and water (12:5:3 v/v/v), according to Bieleski \& Turner (1966). After standing for 24 hours, the extract was centrifuged at $2000 \mathrm{~g}$ for 30 minutes. Aliquots of the supernatant were stored in freezer for posterior determination of phenolic compounds (Swain \& Hillis, 1959), and condensed tannins (Porter, 1989). Further aliquots (4 mL) were taken from the supernatant to which chloroform $(1 \mathrm{~mL})$ and water $(1.5 \mathrm{~mL})$ were added, and shaken. After 24 hours in a refrigerator, when phase separation occurred, the lower phase was removed and discarded. The upper aqueous phase was concentrated on water bath at $45^{\circ} \mathrm{C}$ for 8 hours, and kept in a freezer until the determination of amino acids (Cocking \& Yemm, 1954) and nitrate (Cataldo et al., 1975).

The residue obtained after centrifugation of the extract was suspended in $0.1 \mathrm{~N} \mathrm{NaOH}$, left to rest for 24 hours, and then centrifuged at $2000 \mathrm{~g}$ for $30 \mathrm{~min}$ utes. The supernatant was used for the determination of total proteins (Bradford, 1976).

\section{Determination of chlorophyll}

Chlorophyll was extracted according to Hiscox \& Israelstam (1979). Portions of leaves (20 mg fresh weight) were immersed in dimethyl-sulphoxide (DMSO) in sealed tubes kept in the dark. The tubes were incubated in a water-bath at $65^{\circ} \mathrm{C}$ for 30 minutes and cooled to room temperature. Total chlorophyll content was calculated according to Arnon (1949) and Lichtenthaler \& Wellburn (1983).

\section{Determination of total tissue nitrogen}

Samples of $100 \mathrm{mg}$ of the leaves dried at $65^{\circ} \mathrm{C}$ for 7 days were placed in digestion tubes (Folin-Wu type), containing $1 \mathrm{~g}$ of catalyst ( $100 \mathrm{~g}$ of $\mathrm{K}_{2} \mathrm{SO}_{4}, 10$ $\mathrm{g}$ of $\mathrm{CuSO}_{4} \cdot 5 \mathrm{H}_{2} \mathrm{O}$, and $1 \mathrm{~g}$ of $\mathrm{Se}$ ), $3 \mathrm{~mL}$ of concentrated sulphuric acid and $1 \mathrm{~mL}$ of hydrogen peroxide $\left(\mathrm{H}_{2} \mathrm{O}_{2}\right)$. The samples were digested at $360^{\circ} \mathrm{C}$ and nitrogen determined by the Kjeldahl method (Nelson \& Sommers, 1973).

\section{Experimental design and statistical analysis}

Ten replicates (each represented by one leaf for each plant) were used for leaf life span and leaf growth curves and five replicates were used in biochemical analysis in a completely randomized design. Statistical analysis was performed using the software SAS/STAT (1990). The data were analysed for normal distribution using the Kolmogorov-Smirnov test. The data were subjected to an analysis of variance and means compared for significant differences by Duncan's Multiple Range test $(\alpha=0.05)$.

\section{RESULTS AND DISCUSSION}

Leaf longevity and SLM values for the four species are shown in Table 1. Semideciduous species (H. courbaril and L. guilleminianus) presented leaf life spans at least twice as long as those of the deciduous species ( $P$. dubium and E. contortisiliquum). Greater leaf longevity in some species is per se a mechanism of nutrient economy, since it reduces mineral loss (Carrera et al., 2000; 2003).

The semideciduous species also revealed significantly greater values of SLM compared to deciduous, which is consistent with the findings of Peeters (2002) that a correlation exists between morphological characteristics of a leaf and the duration of its life cycle, as well as with the earlier observations that species showing greater leaf longevity present a greater SLM (Castro-Díez et al., 2000; Prior et al., 2003; Wright et al., 2002). It is believed that a reciprocal relationship exists between SLM and the life span of the leaf in that a smaller SLM indicates a greater potential for the rapid production of biomass in view of the proportionally greater area for harvesting light, while a longer leaf life span indicates a longer duration of biomass yield (Westoby, 1998), and nutrient conservation (Aerts \& Chapin, 2000; Navas et al., 2003).

Table 1 - Leaf life span and specific leaf mass (SLM) of mature green leaves of semideciduous (Hymenaea courbaril and Lonchocarpus guilleminianus) and deciduous (Peltophorum dubium and Enterolobium contortisiliquum) arboreal species.

\begin{tabular}{lcc}
\hline Species & Leaf life span & SLM \\
\hline \multicolumn{1}{c}{ days } & g DM cm ${ }^{-2}$ \\
H. courbaril & $419 \pm 54.8$ a & $0.0065 \pm 0.0003$ a \\
L. guilleminianus & $340 \pm 9.7 \mathrm{~b}$ & $0.0072 \pm 0.0015 \mathrm{a}$ \\
P. dubium & $152 \pm 23.1 \mathrm{c}$ & $0.0046 \pm 0.0006 \mathrm{~b}$ \\
E. contortisiliquum & $139 \pm 11.9 \mathrm{c}$ & $0.0053 \pm 0.0003 \mathrm{~b}$ \\
\hline$\pm=$ mean standard error. Means followed by a different letters \\
$\begin{array}{l}\text { differ by Duncan's Multiple Range test }(\alpha=0.05) . \\
\text { mass }\end{array}$
\end{tabular}


Coley (1988) relates leaf longevity to the concentration of secondary compounds. Species with greater leaf life spans (H. courbaril and L. guilleminianus) presented higher concentrations of phenolic compounds than the shorter life span species (Figure 1A). Although the concentration of total phenolics produced a direct relationship to leaf longevity, this did not occur with tannin content (Figure 1B). The semideciduous species showed lower concentrations of these compounds than the deciduous (P. dubium and E. contortisiliquum), which is in agreement with the work of Aerts (1995), who registered when comparing perennial and deciduous species, that tannins are generally found in lower concentrations in species with longer-lasting leaves. Differences in the concentration of diverse types of phenolics can be explained by the fact that their synthesis has high energy cost, and this cost will determine the amounts produced (Aerts et al., 1999).

Some authors suggest that the formation of leaves with long life spans is a costly process in view of the greater investment required for defense compounds and structural components (Kikusawa, 1991). The building cost per unit of leaf mass has

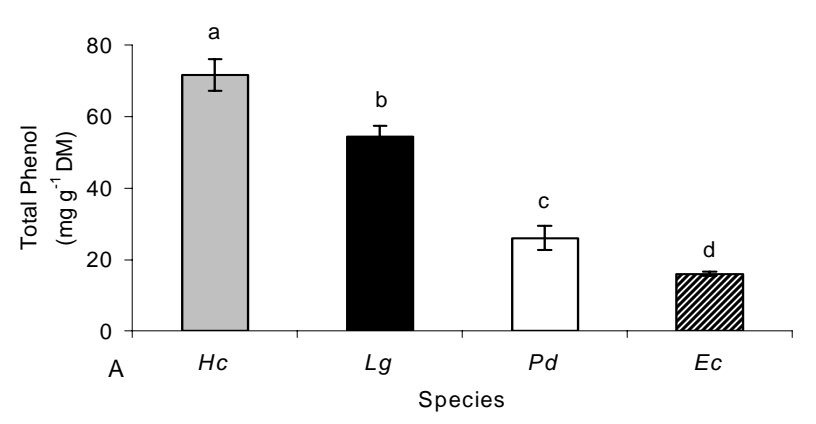

been proposed to be the result of a negative correlation between costly compounds involved in rapid metabolic activity, such as proteins, and those related to leaf persistence, such as phenolics (Martínez et al., 2002). Our data are consistent with this proposal, since the species with greater leaf life spans presented lower contents of soluble proteins (Figure 2). Similar data have been reported by Haddad et al. (2004). Takashima et al. (2004) proposed that species with greater leaf life spans invest more in cell wall (insoluble) proteins, in detriment of those (soluble) proteins related to photosynthetic activity, whereas for deciduous species the opposite is found.

Besides proteins, other nitrogenous compounds were related to leaf life span. Our data (Figures 3 and 4) are in agreement with literature report showing that, for species with longer life span leaves, a lower level was found for nitrate (Figure 3) (Schimidt et al., 1998), chlorophyll (Haddad et al., 2004; Prior et al., 2003), and total N (Figure 4) (Haddad et al., 2004; Prior et al., 2003) compared with species with a short foliar life span.

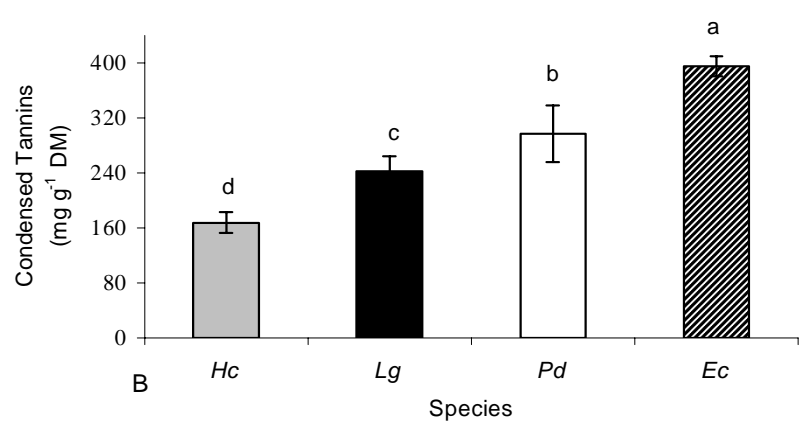

Figure 1 - Concentration of phenolic compounds (A - total phenolics and B - condensed tannins) expressed on a dry mass (DM) basis in mature green leaves of arboreal legumes: Hc - Hymenaea courbaril (semideciduous), L $g$ - Lonchocarpus guilleminianus (semidecídua), Pd - Peltophorum dubium (deciduous) and Ec - Enterolobium contortisiliquum (deciduous). Vertical bars represent standard error of the mean (in some cases the error bar was smaller than the symbol). Means followed by different letters differ by Duncan's Muliple Range test $(\alpha=0.05)$.
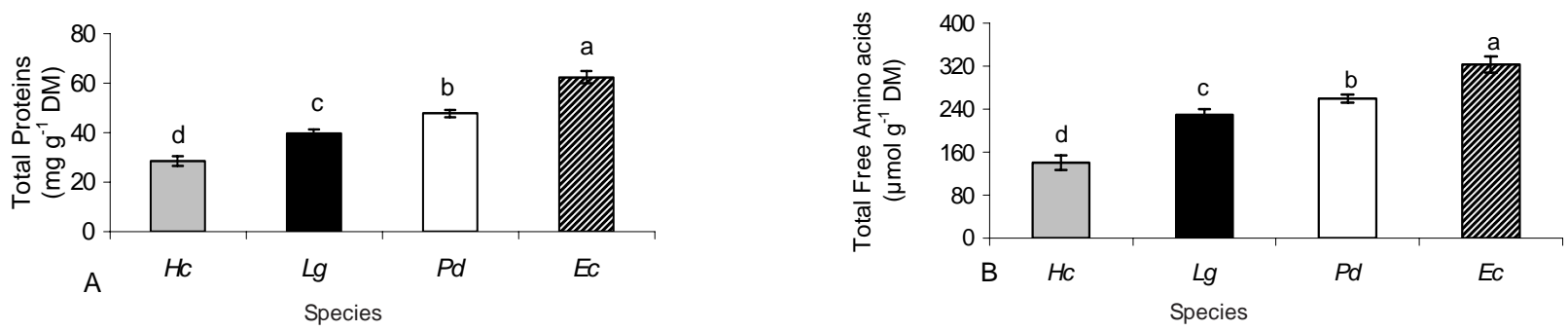

Figure 2 - Concentration of nitrogenous compounds (A - total soluble proteins, B - free amino acids) expressed on a dry mass (DM) basis in mature green leaves of the arboreal legumes: Hc - Hymenaea courbaril (semideciduous), Lg - Lonchocarpus guilleminianus (semideciduous), Pd - Peltophorum dubium (deciduous) and Ec - Enterolobium contortisiliquum (deciduous). Vertical bars represent standard error of the mean (in some cases the error bar was smaller than the symbol). Means followed by different letters differ by Duncan's Muliple Range test $(\alpha=0.05)$. 

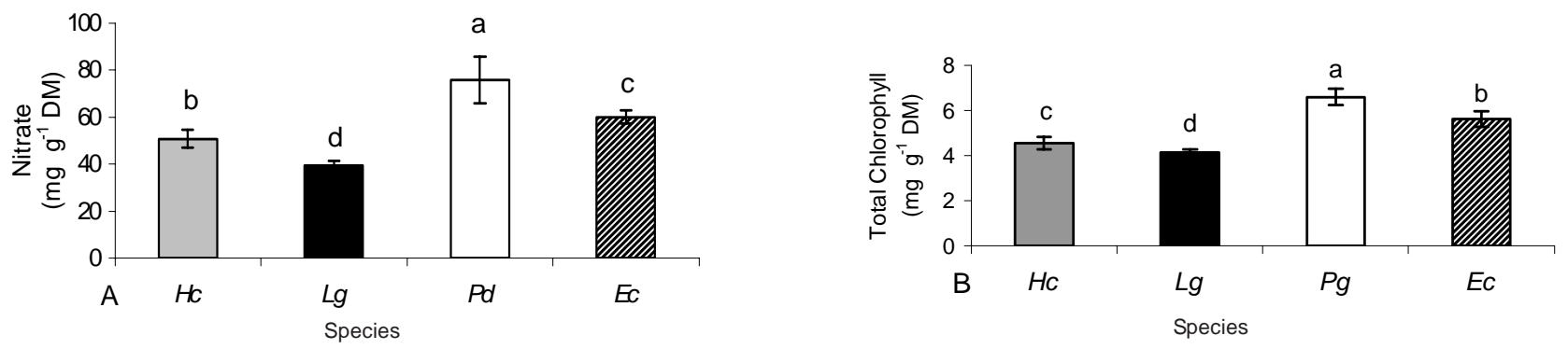

Figure 3 - Concentration of nitrogenous compounds (A - nitrate, B - total chlorophyll) expressed on a dry mass (DM) basis in mature green leaves of the arboreal legumes: Hc - Hymenaea courbaril (semideciduous), Lg - Lonchocarpus guilleminianus (semideciduous), Pd - Peltophorum dubium (deciduous) and Ec - Enterolobium contortisiliquum (deciduous). Vertical bars represent standard error of the mean (in some cases the error bar was smaller than the symbol). Means followed by different letters differ by Duncan's Muliple Range test $(\alpha=0.05)$.

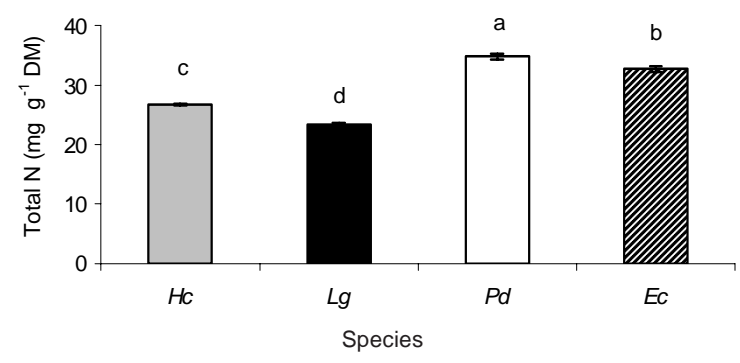

Figure 4 - Total $\mathrm{N}$ expressed on a dry mass (DM) basis in mature green leaves of the arboreal legumes: Hc - Hymenaea courbaril (semideciduous), Lg - Lonchocarpus guilleminianus (semideciduous), Pd - Peltophorum dubium (deciduous) and Ec - Enterolobium contortisiliquum (deciduous). Vertical bars represent standard error of the mean (in some cases the error bar was smaller than the symbol). Means followed by different letters differ by Duncan's Muliple Range test $(\alpha=0.05)$.

\section{ACKNOWLEDGEMENTS}

We wish to acknowledge the Fundação José Pedro de Oliveira (Reserva Mata de Santa Genebra) for allowing seed and soil collection, and Dr. Ladaslav Sodek for his assistance with the English version of the manuscript. A. L. S. L. is grateful to the Coordenação de Aperfeiçoamento de Pessoal de Nível Superior (CAPES) for the award of a fellowship and to the Centro Universitário Luterano de Jí-Paraná, Universidade Luterana do Brasil (CEULJI/ULBRA), for financial support.

\section{REFERENCES}

AERTS, R. Nutrient use efficiency in evergreen and deciduous species from heatlands. Oecologia, v.84, p.391-397, 1990.

AERTS, R. The advantages of being evergreen. Trends in Ecology \& Evolution, v.10, p.402-407, 1995.

AERTS, R.; CHAPIN, F.S. The mineral nutrition of wild plants revisited: a re-evaluation of processes and patterns. Advances in Ecological Research, v.30, p.1-67, 2000.
AERTS, R.; VERHOEVEN, J.T.A.; WHIGHAM, D.F. Plant-mediated controls on nutrient cycling in temperate fens and bogs. Ecology, v.80, p.2170-2181, 1999.

ARAUJO,Q.R.; COMERFORD, N.B.; OGRAM, A.V.; AL-AGELY, A.; SANTOS FILHO, L.P.; SANTOS, J.G. Soil carbon and physical property changes in Brazilian coastal tableland soils with land use following deforestation. Agroforestry Systems, v.63, p.193-198, 2004.

ARNON, D.J. Copper enzymes in isolated chloroplast polyphenoloxidases in Beta vulgaris. Plant Physiology, v.24, p.115, 1949.

BIELESKI, L.R.; TURNER, N.A. Separation and estimation of amino acids in crude plant extracts by thin-layer electrophoresis and chromatography. Analytical Biochemistry, v.17, p.278-293, 1966.

BRADFORD, M.M. A rapid and sensitive method for the quantitation of microgram quantities of protein utilizing the principle of proteindye binding. Analytical Biochemistry, v.72, p.248-254, 1976.

CARRERA, A.L.; SAIN, C.L.; BERTILLER, M.B. Patterns of nitrogen conservation in shrubs and grasses in the Patagonian Monte, Argentina. Plant and Soil, v.224, p.185-193, 2000.

CARRERA, A.L.; BERTILLER, M.B.; SAIN, C.L.; MAZZARINO, M.J. Relationship between plant nitrogen conservation strategies and the dynamics of soil nitrogen in the arid Patagonian Monte, Argentina. Plant and Soil, v.255, p.595-604, 2003.

CASTRO-DÍEZ, P.; PUYRAVAUD, J.P.; CORNELISSEN, J.H.C. Leaf structure and anatomy as related to leaf mass per area variation in seedlings of a wide range of woody plant species and types. Oecologia, v.124, p.476-486, 2000.

CATALDO, D.A.; HAROON, M.; SCHRADER, L.E.; YOUNGS, V.L. Rapid colorimetric determination of nitrate in plant tissue by nitration of salicylic acid. Communications in Soil Science and Plant Analysis, v.6, p.71-80, 1975.

CHABOT, B.F.; HICKS, D.J. The ecology of leaf life spans. Annual Review of Ecology and Systematics, v.13, p.229-259, 1982.

COCKING, E.C.; YEMM, E.W. Estimation of amino acids by ninhidrin. Biochemistry Journal, v.58, p.12-13, 1954.

COLEY, P.H. Effects of plant growth rate and leaf lifetime on the amount and type of anti-herbivore defense. Oecologia, v.74, p.531-536, 1988.

COLEY, P.D.; BRYANT, J.P.; CHAPIN, F.S. Resource availability and plant antiherbivore defense. Science, v.230, p.895-899, 1985.

CORDELL, S.; GOLDSTEIN, G.; MEINZER, F.C.; VITOUSEK, P.M. Regulation of leaf life-span and nutrient-use efficiency of Metrosideros polymorpha trees at two extremes of a long chronosequence in Hawai. Oecologia, v.127, p.198-206, 2001.

EAMUS, D.; PRICHARD, H. A cost-benefit analysis of leaves of four Australian savanna species. Tree Physiology, v.18, p.537-545, 1998.

HADDAD, C.R.B.; LEMOS, D.P.; MAZZAFERA, P. Leaf life span and nitrogen in semideciduous forest tree species (Croton priscus and Hymenaea courbaril). Scientia Agricola, v.61, p.462-46, 2004. 
HAUKIOJA, E.; NIEMELÄ, P.; SIRÉN, S. Foliage phenols and nitrogen in relation to growth, insect damage, and ability to recover after defoliation, in the mountain birch Betula pubescens ssp tortuosa. Oecolologia, v.65, p.214-222, 1985.

HISCOX, J.D.; ISRAELSTAM, G.F. A. method for the extraction of chorophyll from leaf tissue without maceration. Canadian Journal of Botany, v.57, p.1332-1334, 1979.

HUDGINS, J.W.; CHRISTIANSEN, E.; FRANCESCHI, V.R. 2003. Methyl jasmonate induces changes mimicking anatomical defences in diverse members of the Pinaceae. Tree Physiology, v.23, p.361371, 2003.

INGESTAD, T.; LUND, A. Nitrogen stress in birch seedlings: I. Growth technique and growth. Physiologia Plantarum, v.45, p.137-148, 1979.

KIKUSAWA, K. A cost - benefit analysis of leaf habitat and leaf longevity of trees and their geographical pattern. The American Naturalist, v.138, p.1250-1263, 1991.

KOUKI, M.; MANETAS, Y. Resource availability affects differentially the levels of gallotannins and condensed tannins in Ceratonia siliqua. Biochemical Systematics and Ecology, v.30, p.631-639, 2002.

LICHTENTHALER, B.K.; WELLBURN, A.R. Determination of total carotenoids and chlorophylls a and $\mathrm{b}$ of leaf extracts in different solvents. Biochemical Society Transactions, v.11, p.591-592, 1983.

LORENZI, H. Árvores brasileiras. Nova Odessa: Editora Plantarum, 1992. 352p.

MARTÍNEZ, F.; LAZO, Y.O.; FERNÁNDEZ-GALIANO, R.M.; MERINO, J.A. Chemical composition and construction cost for roots of Mediterranean trees, shrub species and grassland communities. Plant Cell and Environment, v.25, p.601-608, 2002.

MORELLATO, L.P.C. As estações do ano na floresta. In: MORELLATO, L.P.C.; LEITÃO FILHO, H.F. (Ed.) Ecologia e preservação de uma floresta tropical urbana - Reserva de Santa Genebra. Campinas: Editora da UNICAMP, 1995. p.15-18.

MORELLATO, L.P.C.; RODRIGUES, R.R.; LEITÃO-FILHO, H.F.; JOLY, C.A. Estudo comparativo de fenologia de espécies arbóreas de florestas de altitude e mesófila semidecídua na Serra do Japi, Jundiaí, São Paulo. Revista Brasileira de Botânica, v.12, p.85-89, 1989.

NAVAS, M.L.; DUCOUT, B.; ROUMET, C.; RICHARTE, J.; GARNIER, J.; GARNIER, E. Leaf life span, dynamics and construction cost of species from Mediterranean old-fields differing in successional status. New Phytologist, v.159, p.213-228, 2003.
NELSON, D.W.; SOMMERS, L.E. Determination of the total nitrogen in plant material. Agronomy Journal, v.65, p.109-112, 1973.

PEETERS, P.J. Correlations between leaf structural traits and the densities of herbivorous insect guilds. Botanical Journal of the Linnean Society, v.77, p.43-65, 2002.

PORTER, L.J. Tannins. In: DEY, P.M.; HARBONE, J.B. Methods in plant biochemistry. London: Academic Press, 1989. v.1, p.389-419.

PRIOR, L.D.; EAMUS, D.; BOWMAN, D.M.J.S. Leaf attributes in the seasonally dry tropics: a comparison of four habitats in northern Australia. Functional Ecology, v.17, p.504-515, 2003.

READ, J.; EDWARDS, C.; SANSON, G.D.; ARANWELA, N. Relationships between sclerophylly, leaf biomechanical properties and leaf anatomy in some Australian heath and forest species. Plant Biosystems, v.134, p.261-277, 2000.

SAS INSTITUTE. SAS/STAT. Users guide. Version 8. Cary: SAS Institute Inc., 1990. 1 CD-ROOM.

SCHIMIDT, S.; STEWART, G.R.; TURNBULL, M.H.; ERSKINE, P.D.; ASHWATH, N. Nitrogen relations of natural and disturbed plant communities in tropical Australia. Oecologia, v.117, p.95-104, 1998.

SWAIN, T.; HILLIS, W.E. The phenolic constituents of Prunus domestica. I. The quantitative analysis of phenolic constituents. Journal of the Science of Food and Agriculture, v.10, p.63-68, 1959.

TAKASHIMA, T.; HIKOSAKA, K.; HIROSE, T. Photosynthesis or persistence: nitrogen allocation in leaves of evergreen and deciduous Quercus species. Plant Cell Environment, v.27, p.1047-1054, 2004.

VINCENT, J.M. A manual for practical study of the root-nodule bacteria. Oxford: Blackwell Scientific Publications, 1970. 164p.

WESTOBY, M. A leaf-height-seed (LHS) plant ecology strategy scheme. Plant and Soil, v.199, p.213-227, 1998.

WRIGHT, I.J.; WESTOBY, M.; REICH, P.B. Convergence towards higher leaf mass per area in dry and nutrient-poor habitats has different consequences for leaf lifespan. Journal of Ecology, v.90, p.534-543, 2002.

WRIGHT, I.J.; WESTOBY, M. Nutrient conservation, resorption and lifespan: leaf traits of Australian sclerophyll species. Functional Ecology, v.17, p.10-19, 2003.

Received May 06, 2005

Accepted December 28, 2005 